\title{
A Review on the Anti-diabetic Activity of Andrographis paniculata (Burm. f.) Nees based In-vivo Study
}

\author{
Titi Komalasari, Sabtanti Harimurti
}

Department of Pharmacy, Universitas Muhammadiyah Yogyakarta, Indonesia

\begin{tabular}{l}
\hline \hline Article Info \\
\hline Article history: \\
Received Aug 04, 2015 \\
Revised Sept 29, 2015 \\
Accepted Nov 26, 2015
\end{tabular}

\section{Keyword:}

Alternative medicine Andrographis paniculata Andrographolide Diabetes mellitus

\begin{abstract}
Diabetes mellitus (DM) is ricing nowadays. DM is a metabolic deasease characterized by increasing of glucose blood level for prolonged time. Patient with DM must take medicine for lowering glucose levels in whole life. Synthetic anti-diabetic agent is commonly used and significantly able to maintain the glucose blood levels. However, many side effects will occur during the treatment. Further, people are trying to find an alternative medicine for DM treatment. This paper will discuss about an alternative medicine for anti-diabetic agent that is called Andrographis paniculata (Burm. f.) Nees based in-vivo study. Search data obtained from PubMed, PMC (PubMed Central), International Food and Research Journal, and Google search engine. Inclution and exclution criteria were used for selection of journals. Inclution criteria were taken is in-vivo study of Andrographis paniculata as anti-diabetic, published in 2000-2014, and free full text journal or PubReader (full text journal in PubMed Central) in English or Indonesian language. Base on reviewed journals that was conducted, anti-diabetic agent of Andrographis paniculata was found in extract, in fractional coumpund (i.e. andrographolide or its analogue AL-1: andrographolide-lipoic acid), and in combination with synthetic drug or other herbal. Therefore, Andrographis paniculata is potentially developed as an alternative anti-diabetic agent.
\end{abstract}

Copyright (C) 2015 Institute of Advanced Engineering and Science. All rights reserved.

\section{Corresponding Author:}

Titi Komalasari,

Departement of Pharmacy, Faculty of Medical and Health Sciences,

Universitas Muhammadiyah Yogyakarta,

Taman Tirto, Kasihan, Bantul, D.I Yogyakarta, 55183, Indonesia, Phone (0274) 374320.

Email: komalasarit@gmail.com

\section{INTRODUCTION}

Diabetes mellitus (DM) is a metabolic disease in which there are high blood glucose levels over a long period. DM is characterized by hyperglycemic regarding to the damage of metabolism process of carbohydrates, proteins or fats that is causing the impaired insulin secretion, insulin activity or a combination of both. Diabetes is classified into two main types, that are diabetes type 1 or IDDM (insulin-dependent diabetes mellitus) and type 2 or NIDDM (non-insulin-dependent diabetes mellitus) [1]. Type 1 of DM occur due to the destruction of the beta cells and usually followed by insulin deficiency (absolute insulin deficiency) or in the other word that the body can not produce insulin. Whereas, type 2 of DM is a condition when the body still able to produces insulin however there is interference on the process of insulin secretion due to the background of insulin resistance (relative insulin deficiency). In addition to the above two types of $\mathrm{DM}$, there are also diabetes caused by destruction of beta cell function due to genetic factors, deseases of the exocrine pancreas (such as cystic fibrosis), and gestational DM [2].

International Diabetes Federation (IDF) predicted that people with DM reached 371 million in 2012 and 552 million in 2030. The average of the increasing case is 3 people every second [3],[4]. Therefore, it is necessary to find the integrated treatment of DM by using an alternative medicine such as herbal medicine or using a combination between the synthetic drugs and herbal medicine. This paper will discuss intensively 
about the anti-diabetic activity of Andrographis paniculata, a plant species that tradionally used as antidiabetic agent, based on in-vivo study.

\section{RESEARCH METHOD}

Evidence Based Medicine (EBM) from PubMed, PMC (PubMed Central), International Food and Research Journal, and Google search engine for Indonesian language journal on the topic of to the antidiabetic activity of Andrographis paniculata (Burm. f.) Nees were used as the source of this literature review. Andrographis panculata, diabetes, anti-diabetic activity of Andrographis paniculata, and combination of Andrographis paniculata as anti-diabetic were used as the keywords for searching the journals. Inclution and exclution criteria were used for selection of the journals. Inclution criteria were the journals that discuss about in-vivo study of Andrographis paniculata as anti-diabetic, journals published in 2000-2014, and free full text journal or PubReader (full text journal in PubMed Central) published in English or Indonesian language. Meanwhile the exclution criteria were the journals that no have relation between Andrographis paniculata to anti-diabetic activity, journal of other hebal medicine for anti-diabetic and journal not publish in $2000-2014$.

There were seven jounals have been reviewed, five journals published in English and two journals in Indonesian. Each journal then was evaluated on the research objectives, research methods, and parameters used as well as the discussion of research results.

\section{RESULTS AND ANALYSIS}

Recently, the pharmacological and non pharmacological therapies were known as the DM therapy. The pharmacological therapy is commonly using some hypoglycemic oral drugs such as sulfonyl urea, glinid, thiazolidinediones, binguadit, or its combination of these drugs. Pharmacological therapy is also can be done by using insulin injections directly or with DPP-4 inhibitors (insulin sensitizing). While non-pharmacological therapies are some activities that can help to maintain normal glucose blood levels such as changing the lifestyle and behavior (i.e. avoiding smoking and alcohol), taking a good diet, and doing a physical exercise $[5]$.

One alternative therapy for DM is using herbal medicine, which has been chosen by community. Treatment with herbal medicine is more easily accepted by community since it is considered to have low side effects when properly used (proper dosage, indications, timing, manner of use and accuracy of determination material from herbal medicine) [6].

Numbers of research on medicinal plants that potentially developed as an anti-diabetic agent were conducted. Medicinal plants can be used as an alternative treatment for DM is sambiloto (Andrographis paniculata) [6]. Besides as anti-diabetic agent, Andrographis paniculata had also been widely studied as analgetic, antioxidants [6], anti-malarial [7], antibacterial, and hepatoprotector [8].

Andrographis paniculata is containing some phytoconstituent compound such as flavonoids, diterpenoids, and polyphenol [9],[10]. The major compounds inside the Andrographis paniculata which is has a biological activity is a diterpene lactone group, which consists of andrographolide, neoandrographolide, 14-deoxyandrographolide, andrograpin, 14-acetylandrographolide, 14-deoxydehidroandrographolide, and homoandrographolide. Andrographolide is a diterpene lactone compound that most dominant, approximately $4 \%$ of the whole plant [9]. This andrographolide is an active compound as antidiabetes [11].

Various studies related to the pharmacological activity of Andrographis paniculata (especially andrographolide as compounds that have pharmacological activity as anti-diabetic agent) had been carried out both in-vivo and in vitro study. Some of them had been through clinical trials in humans about safety and afficacy. The chemical structure of andrographolide can be seen on Figure 1 [12]. 


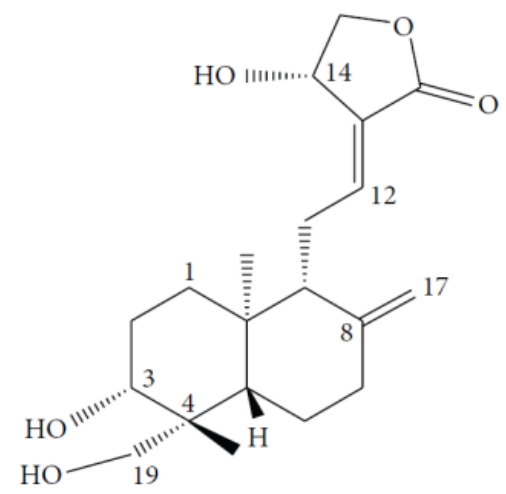

Figure 1. Chemical structure of andrographolide [12]

\subsection{Physicochemical properties of andrographolide}

Andrographolide is the main compound in Andrographis paniculata, especially on the leaves. The IUPAC name of andrographolide is $3 \alpha, 14,15,18$-tetrahydroxy- $5 \beta, 9 \beta \mathrm{h}, 10 \alpha$-labda-8, 12-dien-16-oic acid $\gamma$ lactone (Figure 1). The molecular formula of andrographolide is $\mathrm{C}_{20} \mathrm{H}_{30} \mathrm{O}_{5}$ with molecular weight is 350.4 gram/mole. Andrographolide is not very soluble in water, soluble in acetone, chloroform, ether and ethanol (hot ethanol). Cristalline of andrographolide is highly stable for more than 3 months with the melting point is $235.3{ }^{\circ} \mathrm{C}$. The purity of andrographolide can be determined by Thin-Layer Chromatography (TLC) [12], High Performance Liquid Chromatography (HPLC) [13], or Liquid Chromatography-Mass Spectrometry (LCMS) [12].

Aryani reported that the andrographolide level of Andrographis paniculata at different areas in Indonesia has variation on consentration, starting from $6.25 \%$ in Banyuwangi to $14.69 \%$ in Surabaya. Identification was conducted for $96 \%$ ethanolic extract from maceration process [13]. The Andrographis paniculata extract that can be used as the anti-diabetic agent is a extract that containing andrographolide not less than $15 \%[14]$.

\subsection{Mechanism of induction of diabetes in rats}

During the study of anti-diabetic activity of Andrographis paniculata, rat was used as the animal for the test. In various studies on anti-diabetic activity of a drug on in-vivo study, most researchers use streptozotosin (STZ) [15],[16] or alloxan [17] to induce insulin resistance. Alloxan usually used to induce type 1 diabetes (IDDM), but later revealed that alloxan is not selective for rat pancreatic beta cells. While STZ can be used to induce both types of diabetes (IDDM and NIDDM) with a toxic effect on the beta sel [18],[19]. In few studies [11],[19]-[22] that was included in this review, for induction the insulin resistance was using high fructose-fat fed. The insulin resistence occured due to the increase of fatty acid metabolism in the cells (intracellular) and resulting fatty acid CoA, diacylglycerol, and caramides. The results of this metabolism causing a decrease of the ability of insulin receptors and activate the PI 3-kinase protein that can decrease the activity of GLUT-4 as glucose transporter [23]. The composition of the high fructose-fat fed are feed $(80 \%)$, lard (15\%), and duck egg yolk (5\%) [20] or with a combination of fructose (36\%), lard (15\%), and egg yolks (5\%) [11].

\subsection{Toxicity evaluation of Andrographis Paniculata}

To ensure that the Andrographis paniculata and andrographolide as an anti-diabetic agent can be used safely, it had been conducted a research on the levels of toxicity in some test subjects with a variety of administration route [12]. Detail explanation of toxic effects of Andrographis paniculata and andrographolide can be seen in Table 1. 
Table 1. Dosage and toxicity of Andrographis paniculata and its major natural product andrographolide [12]

\begin{tabular}{cccc}
\hline Product name & Dosage/duration/route & Experimental models & Toxic effects \\
\hline Andrographolide & $10 \mathrm{mg} / \mathrm{kg}$ for 3 weeks & Human & No \\
Andrographolide & $500 \mathrm{mg} / \mathrm{kg} \mathrm{bw}$ for 7 days i.p. & Mice & No \\
Andrographolide & $25-75 \mu \mathrm{M}$ & Platelets & No cytotoxicity \\
Andrographis paniculata & $20 \mathrm{mg} / \mathrm{kg} \mathrm{bw} \mathrm{for} 60$ days, oral & Rats & No \\
Andrographolide & $22-55 \mu \mathrm{g} / \mathrm{kg}$, i.v. & Mice & Lowering mortality \\
Andrographis paniculata & $1 \mathrm{~g} / \mathrm{kg} / \mathrm{day} \mathrm{for} 4,6$, and 8 weeks & Rats & No \\
Andrographolide & $100 \mathrm{mg} / \mathrm{kg}$, i.p. & Mice & No \\
Andrographolide & $10 \mathrm{mg} / \mathrm{kg}$, i.v & Rats & No \\
\hline
\end{tabular}

Note: i.p.: intraperitoneal; i.v.: intravenous; and bw: body weight.

\subsection{Comparison of Andrographis paniculata extract and andrographolide}

Ethanolic extract of Andrographis paniculata in rats that induced by streptozotocin (STZ) had a significant effect on blood glucose levels and decreased the activity of the enzyme glucose-6-phosphatase. However, after 14 days of administration, the hypoglycemic activity was decline [15].

Nugroho et al reported that Andrographis paniculata gave an effect on lowering blood glucose levels in type 2 of diabetic rats induced by high fructose-fat fed. This study compared the ability of Andrographis paniculata extract and andrographolide as active compound for lowering blood glucose levels on various dose [11]. The optimum dosage for ethanolic extract of Andrographis paniculata was 434.6 $\mathrm{mg} / \mathrm{kg}$ bw [20]. Male Wistar rats were used for animals test. The rats were divided into five groups that were given a high fructose-fat fed for 55 days and 1 normal group (not supplied). The five groups consists of two groups was given a purified extract (at the dose of $434.6 \mathrm{mg} / \mathrm{kg}$ bw and $1303.8 \mathrm{mg} / \mathrm{kg}$ bw twice daily, oraly), two groups of andrographolide (at the dose of $1.5 \mathrm{mg} / \mathrm{kg}$ bw and $4.5 \mathrm{mg} / \mathrm{kg}$ bw twice daily) and the metformin group at the dose of $45 \mathrm{mg} / \mathrm{kg}$ bw oraly, twice daily as a standard [11].

The result showed that either extract of Andrographis paniculata or their active compound i.e andrographolide has an activity to reduce the glucose level and reduce the lipid levels $(\mathrm{p}<0.05)$. These results were identified by measuring the increase of blood glucose levels preprandial and postprandial after 55 days compared to the control group and metformin group. There was no significant difference between hypoglycemic effects of Andrographis paniculata extract and synthesis andrographolide on the dose that had been tested [11].

The mechanism of anti-hyperglycemic andrographolid is not determined well yet. However some of the parameters used to determine the activity of Andrographis paniculata as anti-diabetic are as follow: (1) preprandial and postprandial blood glucose levels [11],[20] (2) expression of GLUT-4 protein in muscle tissues [20],[17] (3) hypoglycemic activity of glibenklamide [20] and (4) HOMA-IR index (homeostatic model assessment-insulin resistance) [19].

HOMA-IR index is rarely used for indicator of insulin resistance. This index is calculated by multiplying fasting glucose and fasting insulin levels then divide by a constant. When the HOMA-IR index is low, it means that anti-diabetic activity of the compound/extract higher. Andriawan et al [19] conducted an experiment on anti-diabetic activity of Andrographis paniculata induced by high fructose-fat fed using HOMA-IR as the parameter. The result was a little different than previous study. The best dose to decrease the HOMA-IR index was obtained from purified extract of Andrographis paniculata compared to the andrographolide as the active biological constituent [19] at the dose was $1303.8 \mathrm{mg} / \mathrm{kg}$ bw. Thus, the pure biological active compound (syntetic compound) from a plant is not always better than their extract. This may happen because of in this plant containing other compounds that work synergistically to reduce the glucose blood level.

\subsection{Combination of Andrographis paniculata purified extract with metformin}

Herbal medicine well known about its safety, however numbers of herbal medicine are not widely known by the community, especially in extracts dosage form. The use of herbal medicine alone is not enough to overcome metabolic diseases such as DM. Based on that, sometime the communities combine the herbal medicines and synthetic drugs. However, problems may occur during the treatment. There is an interaction between herbal and synthetic drugs, where herbal medicine can improve the effectiveness of synthetic drugs or contrarily [24].

Syamsul et al [20] had done a research on the efficacy of the combination of purified Andrographis paniculata and metformin in DM type 2 of rat. The male rats of Sprague-Dawley strain was used for the animals test. The diabetic rats were induced by high fructose-fat fed. In this study as much as 36 rats were divided into 6 groups: one group of normal rats and 5 groups of diabetic rats. Diabetic rats groups consisting of a negative control group, positive control group (diabetic rats were given metformin $45 \mathrm{mg} / \mathrm{kg}$ bw), the group given purified extract of Andrographis paniculata at the dose of $434.6 \mathrm{mg} / \mathrm{kg} \mathrm{bw}$, the group given 
combination of metformin at the dose of $45 \mathrm{mg} / \mathrm{kg}$ bw and purified extract of Andrographis paniculata at the dose of $434.6 \mathrm{mg} / \mathrm{kg}$ bw (combination 1), and the last group was given a half dose of metformin $(22.5 \mathrm{mg} / \mathrm{kg}$ bw and purified extract of Andrographis paniculata at the dose of $434.6 \mathrm{mg} / \mathrm{kg} \mathrm{bw}$ ). All groups administered orally twice a day. The consentrasion of the andrographolide in the extract that was used not less than $15 \%$ [14]. The parameter used in the determination of hypoglycemic activity in this study was the expression of GLUT-4 protein in muscle tissue. The more of GLUT-4 protein expression occurred the more glucose was transported to muscle tissue, so that the blood glucose level will decrease [20].

Combination of metformin and purified extract of Andrographis paniculata dropped the metformin activity significantly $(\mathrm{p}<0.05)$ after 55 days. The decrease of metformin activity was might regarding to the drop of metformin absorption. This result was found on the first combination and second combination 20 . Hence, further study on interaction between metformin and purified extract of Andrographis paniculata is needed to avoid the interaction between metformin and Andrographis paniculata extract.

\subsection{Combination of Andrographis paniculata purified extract with other herbal medicine}

During the optimization of the DM therapy often used a combination of several herbal medicines. Nugroho et al [21] had done a research on the effects of combination of n-hexane insoluble fraction of ethanolic extract of Andrographis paniculata (HIFA) with other herbal medicines to improve their antidiabetic effect. In that study, HIFA combined with curcuminoid fraction of Curcuma xanthorriza (CFC) and HIFA combined with ethyl acetate soluble fraction of propolis (ESP).

Figure 2 is showing the combination of HIFA and CFC provides the best hypoglycemic effect compare to HIFA that given singly or in combination with ESP. While at HIFA combination with ESP shows a higher decrease in serum glucose levels than HIFA singly, even though the increase is not significantly. Thus this combination (HIFA-CFC) was potentially developed as the one of chosen therapy using herbal medicine [21].
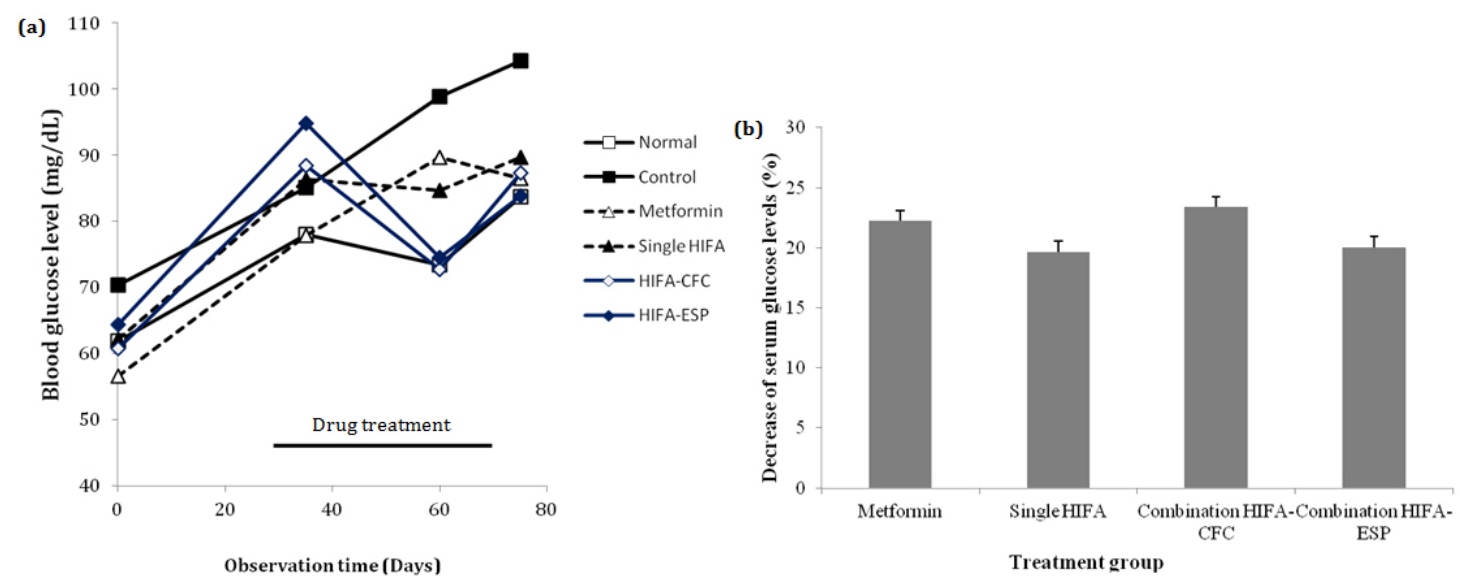

Figure 2. Effect of metformin (positive control), single treatment of HIFA, combination HIFA-CFC, and combination HIFA-ESF on blood glucose levels $(\mathrm{mg} / \mathrm{dL})$ in high-fructose-fat-fed rats (a) and the percentage of reduction in blood glucose levels (b) [21]

Other herbal that can be combined with Andrographis paniculata is Centella asiatica L. Centella asiatica effectively for anti-diabetic in diabetic rats induced by streptozotosin based on measurement of serum levels of glucose and their hepatic glycogen levels [16]. Alkaloids, flavonoids, terpenoids, and saponins are found in the Centella asiatica which are scattered throughout the plant. Important active compound in Centella asiatica is asiaticoside, a triterpen compound [25].

Andrographolide-enriched extract of Andrograpis paniculata (AEEAP) combined with asiaticosideenriched extract of Centella asiatica (AEECA) gave an anti-diabetic effect on diabetic rats induced by highfructose fat fed [22].

Andrographolide-enriched extract of Andrographis paniculata (AEEAP) was made by using a several times of fractionation of n-hexane, ethyl acetate and ethanol. As well as the preparation of asiaticoside-enriched extract of Centella asiatica (AEECA) was similar to the preparation of AEEAP. It was estimated that in the two extracts were andrographolide and asiaticoside with high levels of active constituent, respectively.

IJPHS Vol. 4, No. 4, December 2015: 256-263 
This study was done by combining AEEAP and AEECA at 3 dose ratio (i.e. AEEAP: AEECA = 70:30, 50:50, and 30:70, respectively) compared to the single dose of AEEAP, AEECA, and metformin. The entire test group, either single dose or their combination provide results with significantly lower blood sugar levels $(\mathrm{P}<0.05)$. The best results were obtained from a combination AEEAP and AEECA at ratio $=70: 30$ by decreasing the blood glucose levels to $68.13 \%$, higher than the single dose of metformin that only $62.63 \%$. In addition, except lowering the blood glucose levels, the combination of AEECA and AEEAP was significantly decrese the levels of cholesterol, LDL, triglyserides [22].

\subsection{Analogue of andrographolide}

Study on anti-diabetic activity of Andrographis paniculata was not only at the active compound, i.e. andrographolide. Reseacher start to study the analogue of andrographolid known as andrographolide lipoic acid. This analogue is potentially developed for the alternative agent on diabetes treatment. Andrographolide lipoic acid (AL-1) is a result of the conjugation of andrographolide and lipoic cid (LA) [26] which both of them have anti-diabetic activity. Lipoic acid itself is a health supplement that used extensively in Germany and used in the treatment of symptomatic diabetic neuropathy over 20 years. By looking at the advantages of each component (i.e. andrographolide and lipoic acid), Zhang et al [17] had done a research on the efficacy and possiblelilty of mechanisms action of the conjugate compound of andrographolide and lipoic acid.

Research on the efficacy of AL-1 was using animals test. BALB/c female mice were induced using alloxan to have diabetic mice. Only rats with blood glucose levels higher than $16.7 \mathrm{mM}$ was used in this experiment. Further, the rats were divided into 6 groups: i.e. control group (not given alloxan), the group given AL-1 (at doses of 20, 40, and $80 \mathrm{mg} / \mathrm{kg}$ bw, respectively), the group given andrographolide (at dose of $50 \mathrm{mg} / \mathrm{kg}$ bw that was equal to molar dose of $80 \mathrm{mg} / \mathrm{kg}$ bw AL-1), and the group given gibenklamide at 1.2 $\mathrm{mg} / \mathrm{kg}$ bw as the positive control. All groups were given through intragastric route once a day for 6 days. The parameters used for anti-diabetic activity of AL-1 was by measuring the fasting blood glucose, serum insulin levels, GLUT-4 protein expression, the ability of dysfunction preventive or destruction of beta cells by patologic and immunohistochemical analysis of the mouse pancreas [17].

Blood glucose levels of diabetic rats that were fed with AL-1 at the dose of $80 \mathrm{mg} / \mathrm{kg}$ bw were the group that intensively decrease on the blood glucose levels on the day of 0 , which was about $65 \%$. This change was 2 times higher compared to the andrographolide group with the dose of $50 \mathrm{mg} / \mathrm{kg}$ bw with the decline about $32.3 \%$. Thus, giving AL-1 was more effective in lowering blood glucose levels. While the test of insulin serum levels, AL-1 at dose $80 \mathrm{mg} / \mathrm{kg}$ bw increase the insulin serum levels better than andrographolide at the dose of $50 \mathrm{mg} / \mathrm{kg}$ bw. The same results were also shown on pathologic and immunohistochemical analysis of mouse pancreatic test. In that study, Zhang et al proved that the AL-1 could be one of the anti-diabetic agents by lowering fasting glucose levels as well as protection against beta cell destruction [17].

(A)

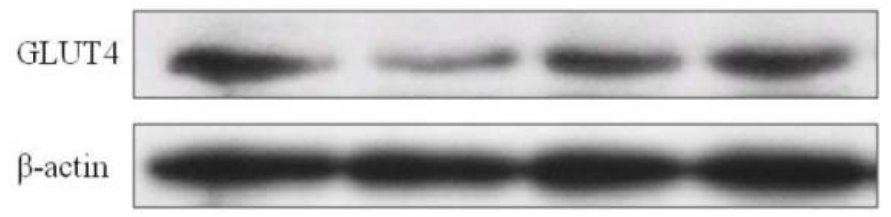

Figure 3. AL-1 elevated GLUT-4 translocation to the plasma membrane of soleus muscles [17]

The soleus muscles were isolated and GLUT-4 contents in plasma were analized using western blot. Figure 3 explain the AL-1 elevated GLUT-4 translocation to the plasma membrane of soleus muscles. GLUT-4 protein levels in diabetic rats only $49.5 \%$ compared to non-diabetic rats. Andrographolide treatment with the dose of $50 \mathrm{mg} / \mathrm{kg}$ bw and AL-1 the dose of $80 \mathrm{mg} / \mathrm{kg}$ bw increases the GLUT-4 protein levels up to $94.6 \%$ and $84.7 \%$, respectively. The mechanism of andrographolide and LA for lowering blood glucose levels was identified by measuring the increase of GLUT-4 expression of protein in muscle tissue. Hence, more glucose was being used in muscle tissue [17],[20],[26]. 


\section{CONCLUSION}

Based on the seven journals that were reviewed, it can be concluded that Andrographis paniculata has an anti-diabetic activity. The anti-diabetic activity of Andrographis paniculata was found in the ethanolic extract and in the fractional coumpund (i.e. andrographolide or its analogue AL-1: andrographolide-lipoic acid). Anti-diabetic activity of Andrographis paniculata was found too in combination with synthetic drug (i.e. metformin). However, Andrographis paniculata decreased metformin absorbtion but not significantly. Combination of Andrographis paniculata with other herbal medicine (i.e. Centella asiatica, Curcuma xanthorriza and propolis) increased Andrographis paniculata activity. Therefore, Andrographis paniculata is potentially developed as an alternative anti-diabetic agent. Further study can explore the mechanism of action of Andrographis paniculata as anti-diabetic in their extract, fractional compound and combination with synthetic drug or other herbal.

\section{REFERENCES}

[1] World Health Organization, Departement of Noncommudicable Disease Surveillance, "Definition, diagnosis, and classification of diabetes mellitus and its complication", pp. 6-13, 1999.

[2] American Diabetes Association, "Standard of medical care in diabetes 2014", Diabetes care, vol/issue: 1(37), pp. 1, 2014.

[3] International diabetes federation, "IDF Diabetes Atlas $5^{\text {th }}$ ed", Brussels: international diabetes federation, 2012. available at www.idf.org/diabetesatlas.

[4] Alice, YY., "Canadian diabetes association 2013 clinical practice guidelines for the prevention and management of diabetes in Canad: Introduction", Can J Diabete, vol/issue: 37(1), pp. S1-S3, 2013.

[5] Eko, V., "Terapi diabetes mellitus", Cermin dunia kedokteran, vol/issue: 38(1), pp. 13-20, 2011.

[6] Karto, "Tingkat manfaat, keamanan, dan efektivitas tanaman obat dan obat tradisional", Karanganyar, Balai Besar Penelitian dan Pengembangan Tanaman Obat dan Obat Tradisional (B2P2TO-OT), Badan Penelitian dan Pengembangan Kesehatan Departemen Kesehatan RI, pp. 5-13, 2008.

[7] Elfita, Muharni, Munawar, Salni, Oktasari A., "Senyawa antimalarial dari jamur endofik tumbuhan sambiloto (Andrographis paniculata Nees)", J Natur Indonesia, vol/issue: 13(2), pp. 123-129, 2011.

[8] Ahmad, I., Aqil, F., Owais, M., "Modern phytomedicine: Turning medicinal plants into drugs", Weinheim: WILEY-VCH Verlag GmbH \& Co. KGaA, pp. 273, 2006.

[9] Bandyopadhyay, SS., Dutta, RP., Mistry, H., "Herbal therapy for diabetes: Phytoconstituent and their mechanism of action", Int J Interdisciplinary Research, vol/issue: 1(6), pp. 4, 2014.

[10] Chao, WW., Lin, BF., "Isolation and identification of bioactive compounds in Andrographis paniculata Chuanxinlian", Chin Med, vol/issue: 13(5), pp. 17, 2010.

[11] Nugroho, AE., Andrie, M., Warditiani, NK., Siswanto, E., Pramono, S., Lukitaningsih, E., “Antidiabetic and antihiperlipidemic effect of Andrographis paniculata (Burm. f.) Nees and andrographolide in high-fructose-fat-fed rats", Indian J Pharmacol, vol/issue: 44(3), pp. 377-381, 2012.

[12] Jayakumar, T., Hsieh, CY., Lee, JJ., Sheu, JR., "Experimental and clinical pharmacology of Andrographis paniculata and its mayor bioactive phytoconstituent andrographolide", Evid Based Complement Alternat Med, vol. 846730, pp. 1-9, 2013.

[13] Aryani, T., "Pengujian validasi analisis kadar andrografolid secara kromatografi cair kinerja tinggi (KCKT) dengan eluasi gradien terhadap ekstrak herba sambiloto (Andrographis paniculata Nees)", Berk. Panel. Hayati, vol. 11, pp. 73-76, 2005.

[14] Departemen kesehatan, "Farmakope herbal Indonesia $1^{\text {st }}$ ed", Jakarta, Depkes RI, pp. 122-4, 2009.

[15] Zhang, XF., Tan, BK., "Anti-diabetic property of ethanolic extract of Andrographis paniculata in streptozotosindiabetic rats", Acta Pharmacol Sin, vol/issue: 21(12), pp. 1157-1164, 2000.

[16] Gayathri, V., Lekshmi, P., Padmanabhan, RN., "Anti-diabetes activity of ethanol extract of Centella asiatica (L.) Urban (whole plant) in Streptozotocin-induced diabetic rats, isolation of an active fraction and toxicity evaluation of the extract", Int J Med Arom Plants, vol/issue: 1(3), pp. 278-286, 2011.

[17] Zhang, Z., Jiang, J., Yu, P., Zeng, X., Larrick, JW., Wang, Y., "Hypoglicemic and beta cell protective effects of andrographolide analogue for diabetes treatment", J Translation Med, vol. 7, pp. 62, 2009. doi:10.1186/1479-58767-62.

[18] Szkudelski, T., "The mechanism of alloxan and streptozotocin action in B cell of the rat pancreas", Physiol. Re, vol. 50, pp. 536-546, 2001.

[19] Adriawan, IR., Andrie, M., Susilowati, R., Pramono, S., Nugroho, AE., "Evaluasi efek anti-diabetes mellitus ekstrak terpurifikasi Andrographis paniculata (Burm. f.) Ness dan andrographolide dengan parameter indeks HOMA-IR”, Trad. Med. J, vol/issue: 19(1), pp. 19-23, 2014.

[20] Syamsul, ES., Nugroho, AE., Pramono, S., "Aktivitas antidiabetes kombinasi ekstrak terpurifikasi herba sambiloto (Andrographis paniculata (Burm. f.) Nees.) dan metformin pada tikus DM tipe 2 resistensi insulin”, Majalah Obat Tradisional, vol/issue: 16(3), pp. 124-131, 2011.

[21] Nugroho, AE., Kusumaramdani, G., Widyaniggar, A., Anggoro, DP., Pramono, S., "Antidiabetic effect of combination of n-hexane insoluble fraction of ethanolic extract of Andrographis paniculata with other traditional medicines", Int Food Research J, vol/issue: 21(2), pp. 785-789, 2014. 
[22] Nugroho, AE., Lindawati, NY., Herlyanti, K., Widyastuti, L., Pramono, S., “Antidiabetic effect of a combination of andrographolide-enriched extract of Androgpraphis paniculata (Burm F.) Nees and asiaticoside-enriched extract of Centella asiatica L. in high fructose-fat fed rats", Indian J Exp Biol, vol 51, pp. 1101-1108, 2013.

[23] Shulman, GI., "Cellular mechanism of insulin resistance", J Clin Investigation, vol/issue: 106(2), pp 171-3, 2000.

[24] Williamson, E., Driver, S., Baxter, K., "Stockley's: Herbal Medicines Interactions”, London: Pharmaceutical Press, pp. 2, 2009.

[25] Birandar, SR., Rachetti, BD., "Extraction of some secondary metabolites \& thin layer chromatography from different parts of Centella asiatica L. (URB)", American J Life Sci, vol/issue: 1(6), pp. 243-247, 2013.

[26] Konrad, D., Somwar, R., Sweeney, G., Yaworsky, K., Hayashi, M., Ramlal, T., Klip, A., "The antihyperglycemic drug $\alpha$-lipoic acid stimulates glucose uptake via both GLUT4 translocation and GLUT4 activation: Potential role of p38 mitogen-activated protein kinase in GLUT4 activation”, Diabetes, vol. 1464-1471, 2001. 